AperTO - Archivio Istituzionale Open Access dell'Università di Torino

\title{
Clastogenic effects of bisphenol A on human cultured lymphocytes
}

\section{This is the author's manuscript}

Original Citation:

\section{Availability:}

This version is available http://hdl.handle.net/2318/1624718

since 2018-05-02T15:19:22Z

Published version:

DOI:10.1177/0960327117693069

Terms of use:

Open Access

Anyone can freely access the full text of works made available as "Open Access". Works made available under a Creative Commons license can be used according to the terms and conditions of said license. Use of all other works requires consent of the right holder (author or publisher) if not exempted from copyright protection by the applicable law. 
Human \& Experimental Toxicology

\section{Clastogenic Effects of Bisphenol-A on Human Cultured Lymphocytes}

\begin{tabular}{|c|c|}
\hline Journal: & Human and Experimental Toxicology \\
\hline Manuscript ID & HET-16-0460.R1 \\
\hline Manuscript Type: & Original Article \\
\hline Date Submitted by the Author: & $\mathrm{n} / \mathrm{a}$ \\
\hline Complete List of Authors: & $\begin{array}{l}\text { Santovito, Alfredo; University of Turin, Department of Life Sciences and } \\
\text { Systems Biology } \\
\text { Cannarsa, Elio; University of Turin, Department of Life Sciences and } \\
\text { Systems Biology } \\
\text { Schleicherova, Dáša ; University of Turin, Department of Life Sciences and } \\
\text { Systems Biology } \\
\text { Cervella, Piero; University of Turin, Department of Life Sciences and } \\
\text { Sistems Biology }\end{array}$ \\
\hline Keyword: & $\begin{array}{l}\text { endocrine disruptors, micronucleus assay, chromosomal aberrations assay, } \\
\text { human lymphocytes, BP-A }\end{array}$ \\
\hline Abstract: & $\begin{array}{l}\text { Bisphenol-A is an endocrine disrupting compound widely used in the } \\
\text { production of polycarbonate plastics and epoxy resins. It is ubiquitously } \\
\text { present in the environment, mostly in aquatic environments, with } \\
\text { consequent risks to the health of aquatic organisms and humans. In the } \\
\text { present study we analysed the cytogenetic effects of bisphenol-A on human } \\
\text { lymphocytes using in vitro chromosomal aberrations and micronuclei } \\
\text { assays. Lymphocyte cultures were exposed to five different concentrations } \\
\text { of BP-A }(0.20,0.10,0.05,0.02 \text { and } 0.01 \mu \mathrm{g} / \mathrm{mL} \text { ) for } 24 \mathrm{~h} \text { (for } \\
\text { chromosomal aberrations test) and } 48 \mathrm{~h} \text { (for micronuclei test). The } \\
\text { concentration of } 0.05 \mu \mathrm{g} / \mathrm{mL} \text { represents the reference dose established by } \\
\text { United States Environmental Protection Agency; } 0.02 \mu \mathrm{g} / \mathrm{mL} \text { represents the } \\
\text { higher concentration of unconjugated BP-A found in human serum and } \\
0.01 \mu \mathrm{g} / \mathrm{mL} \text { represents the tolerable daily intake established by European } \\
\text { Union. Data obtained with both assays showed significant genotoxic effects } \\
\text { of the bisphenol-A at concentrations of } 0.20,0.10 \text { and } 0.05 \mu \mathrm{g} / \mathrm{mL} \text {, } \\
\text { whereas at the concentration of } 0.02 \mu \mathrm{m} / \mathrm{mL} \text { we observed only a significant } \\
\text { increase in the micronuclei frequency. Finally, at the concentration of } 0.01 \\
\mu \mathrm{g} / \mathrm{mL} \text { no cytogenetic effects were observed, indicating this latter as a } \\
\text { more tolerable concentration for human health with respect to } 0.05 \mu \mathrm{g} / \mathrm{mL} \text {, } \\
\text { the reference dose established by US EPA. }\end{array}$ \\
\hline
\end{tabular}




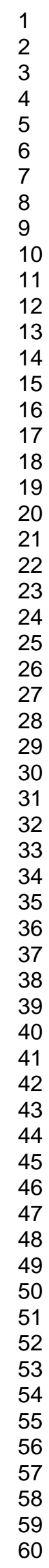

SCHOLARONE"

Manuscripts

7

25

26

27

29

30

32

33

34

36

37

39

40

41

42

44

45

46

47

48

50

51

52

53

54

56

57

58

59

60

http://mc.manuscriptcentral.com/het 
Title: Clastogenic Effects of Bisphenol-A on Human Cultured Lymphocytes

Short Title: Effects of Bisphenol-A on Human Lymphocytes

Authors: Alfredo SANTOVITO*, Elio CANNARSA, Dáša SCHLEICHEROVA, Piero

CERVELLA

University of Turin, Department of Life Sciences and Systems Biology, Via Accademia Albertina

n. 13, 10123 Torino (Italy)

*Corresponding Author:

Alfredo SANTOVITO

Department of Life Sciences and Systems Biology

Via Accademia Albertina n. 13

10123 - Torino (Italy)

Tel.: +39-0116704554

Fax: +39-0116704508 


\section{Summary}

Bisphenol-A is an endocrine disrupting compound widely used in the production of polycarbonate plastics and epoxy resins. It is ubiquitously present in the environment, mostly in aquatic environments, with consequent risks to the health of aquatic organisms and humans. In the present study we analysed the cytogenetic effects of bisphenol-A on human lymphocytes using in vitro chromosomal aberrations and micronuclei assays. Lymphocyte cultures were exposed to five different concentrations of BP-A $(0.20,0.10,0.05,0.02$ and $0.01 \mu \mathrm{g} / \mathrm{mL}$ ) for $24 \mathrm{~h}$ (for chromosomal aberrations test) and $48 \mathrm{~h}$ (for micronuclei test). The concentration of $0.05 \mu \mathrm{g} / \mathrm{mL}$ represents the reference dose established by United States Environmental Protection Agency; $0.02 \mu \mathrm{g} / \mathrm{mL}$ represents the higher concentration of unconjugated BP-A found in human serum and $0.01 \mu \mathrm{g} / \mathrm{mL}$ represents the tolerable daily intake established by European Union. Data obtained with both assays showed significant genotoxic effects of the bisphenol-A at concentrations of $0.20,0.10$ and 0.05 $\mu \mathrm{g} / \mathrm{mL}$, whereas at the concentration of $0.02 \mu \mathrm{g} / \mathrm{mL}$ we observed only a significant increase in the micronuclei frequency. Finally, at the concentration of $0.01 \mu \mathrm{g} / \mathrm{mL}$ no cytogenetic effects were observed, indicating this latter as a more tolerable concentration for human health with respect to $0.05 \mu \mathrm{g} / \mathrm{mL}$, the reference dose established by US EPA.

\section{Keywords:}

BP-A, endocrine disruptors, micronucleus assay, chromosomal aberrations assay, human lymphocytes. 


\section{Introduction}

In the last decades, global production of plastic has continued to rise. Recovery and recycling, however, remain insufficient and millions of tons of plastic compounds continue to accumulate in the environment. Most of these compounds have adverse effects on the biome and pose huge risks for the human health. Some of them are reported to be endocrine disrupting compounds (EDCs), mimicking or blocking natural hormone action and altering the normal functioning of the endocrine system of invertebrate and mammals species. ${ }^{1}$

Among EDCs, bisphenol A (BP-A: 4,4'-(propane-2,2-diyl)diphenol) has received much attention due to its high production volume and widespread human exposur. ${ }^{2} \mathrm{BP}-\mathrm{A}$ is an important synthetic compound used in the production of polycarbonate plastics and as a precursor of epoxy resins. A wide range of consumer products contain BP-A, including water and baby bottles, food packaging materials, internal coatings of cans and drums, toys, water pipes, sports equipment, medical and dental devices, and household electronics. ${ }^{3}$

Due to the daily use, BP-A was found in all environmental matrices such as air, water, soil, sediment, and sewage sludge. It is released into the environment either through sewage treatment effluent, landfill leachate, untreated urban and industrial wastewater or natural degradation of polycarbonate plastics. ${ }^{4}$ For these reasons, BP-A was found at relatively high concentrations (up to hundreds of $\mu \mathrm{g} / \mathrm{L}$ ) in several rivers and lakes worldwide. ${ }^{5}$

Being BP-A used for food packaging, bottles, and coatings for tins, human exposure to this compound is extremely variable depending on life-styles, principally dietary consumption habits. In general, humans are chronically exposed to low doses of the compound, mainly through food and drinking water. ${ }^{6}$ However, the release of BP-A from polycarbonates is accelerated by UV light, aging, heating, or following $\mathrm{pH}$ changes due to the contact with acidic or basic compounds. ${ }^{7}$ It has been shown that upon long-term heating BP-A can leach from plastic baby bottles into an aqueous solution. ${ }^{8}$ For these reasons, firstly in Canada, Denmark and next in all European countries, BP-A 
has been banned in infant formula bottles. ${ }^{9}$

Neverthless, many plastic food and drinking containers still contain BP-A and its presence has been reported in human serum and in $95 \%$ of the urine samples obtained from a reference population in the United States, ${ }^{10}$ as well as in maternal and fetal plasma, ${ }^{11}$ placental tissue, ${ }^{12}$ and in the milk of lactating mothers. ${ }^{13}$ Several studies, using different analytical techniques, have also measured the unconjugated BPA concentrations in human serum, reporting values ranging from 0.2 to $20 \mathrm{ng} / \mathrm{mL}^{2}$ Finally, the estimated exposure of the general population to BP-A is supposed to reach a body burden of up to $9 \mu \mathrm{g} / \mathrm{kg} /$ day. ${ }^{14}$

In humans, BP-A is rapidly absorbed from the gastrointestinal tract and conjugated with glucuronic acid in the liver. The formed glucuronide is then cleared from blood by elimination with urine within $24 \mathrm{~h}$ after oral administration. This rapid excretion results in a low body burden of the BP-A in humans following oral absorption of low doses. ${ }^{15}$ However, despite its rapid rate of excretion, as consequence of its ubiquitous and widespread distribution, BP-A has arisen worldwide concerns about its possible associations with human diseases such as obesity ${ }^{6}$ and cancer. ${ }^{16}$ At reproductive system level, exposure to ECDs seems to be associated with decreased fertility and increased risk of testicular or prostate cancer in men, ${ }^{17}$ whereas in women exposure to ECDs seems to increase the risk of endometriosis, reproductive or other endocrine-related cancers. ${ }^{18}$

From the genetic point of view, the genotoxicity of BP-A has been evaluated in several in vitro and in vivo studies, although with controversial results. BP-A was found to be able to induce increase of chromosome aberrations (CAs) and DNA adducts in Syrian hamster embryo cells, ${ }^{19}$ micronuclei (MNs) in human MCL-5 cells ${ }^{20}$ and in fish erythrocytes, ${ }^{21} \mathrm{MNs}$ and CAs formation in CHO cells. $^{22}$ A significant genotoxic effect by BP-A was also seen on bovine peripheral lymphocytes in vitro, but only at the highest concentration of $1 \times 10^{-4} \mathrm{M} .{ }^{23}$ Moreover, Tiwari et al. ${ }^{24}$ observed a significant increase of MNs in polychromatic erythrocytes, structural CAs in bone marrow cells and DNA damage in lymphocytes of rats exposed to BP-A. Interestingly, in HEK293 cells, BP-A was found to alter the expression of some genes involved in important biological processes including 
ion transport, cysteine and glycogen metabolic processes, apoptosis, DNA damage repair and many others $^{25}$.

On the other hand, BP-A failed to induce gene mutations in Syrian hamster cells, ${ }^{19}$ polyploidy or MNs in male mice, ${ }^{26}$ and sister chromatid exchanges in mouse lymphoma cells. ${ }^{27}$

Nevertheless, based on published data, the United States Environmental Protection Agency (US EPA) has set a reference dose (RD) for BP-A oral exposure of $0.05 \mathrm{mg} / \mathrm{kg}$ body weight (BW)/day. ${ }^{28}$ More recently, the European Union (EU) ${ }^{14}$ established a temporary tolerable daily intake (TDI) for BPA of $10 \mu \mathrm{g} / \mathrm{kg} \mathrm{BW} /$ day, based on a consideration of much toxicological data, including the effects of BPA on reproductive organs and functions, and hormonal effects in animals.

No data are reported in literature about in vitro cytogenetic effects of BP-A on human lymphocytes. For this reason, in the present study we assessed the possible in vitro clastogenic and aneugenic effects of BP-A exposure on human lymphocyte cells, by CAs and MNs assays.

It has been shown that a high frequency of the chromosomal damage is a predictive value of health risk. ${ }^{29}$ In this scenario, CAs and MNs assays are important tools in the measurement of the genotoxic potential of many chemicals, including BP-A. The CAs assay allows the detection of cells carrying unstable aberrations (chromosome and chromatid breaks, deletions, fragments, rings, dicentrics and chromatid exchanges) that will lead to cell death during proliferation. ${ }^{30}$ Previous studies have provided strong evidence in support of the hypothesis that high CAs frequency in peripheral blood lymphocytes is a powerful predictor of cancer risk. Indeed, it is known that cancer incidence among healthy individuals of a population increases with increased levels of CAs in their circulating lymphocytes. ${ }^{29}$ On the other hand, MNs are used as a fast and reliable assay for detecting both potential clastogenic (chromosome breakage) or aneugenic (chromosome lagging due to dysfunction of mitotic apparatus) effects of different xenobiotics. In particular, MNs represent acentric chromosomal fragments or whole chromosomes left behind during mitotic cell division and appear in the cytoplasm of interphase cells as small additional nuclei. Bonassi et al. ${ }^{31}$ 
provided evidences that also increased MNs frequencies in peripheral blood lymphocytes are positively associated with early events in carcinogenesis.

In the present study, we tested concentrations of $0.20,0.10,0.05,0.02$ and $0.01 \mu \mathrm{g} / \mathrm{mL}$, where 0.05

$\mu \mathrm{g} / \mathrm{mL}$ represents the RD established by US EPA; ${ }^{28} 0.20 \mu \mathrm{g} / \mathrm{mL}$ and $0.10 \mu \mathrm{g} / \mathrm{mL}$ are multiples of this RD in order to establish a possible dose-dependent increase of the genomic damage; 0.020 $\mu \mathrm{g} / \mathrm{mL}$ represents the higher concentration of unconjugated BP-A found in literature in human serum, ${ }^{2}$ and $0.01 \mu \mathrm{g} / \mathrm{mL}$ is the TDI established by EU. ${ }^{14}$

\section{Methods}

\subsection{Chemicals and Media}

The IUPAC name of Bisphenol-A (BP-A, CAS n. 80-05-7) is: 4,4'-(propane-2,2-diyl)diphenol. The BP-A was dissolved in Dimethyl Sulfoxide (DMSO, CAS no. 67-68-5). Gibco RPMI 1640 cell culture media supplemented with L-glutamine, foetal calf serum, phytohemagglutinin (PHA), and antibiotics were purchased from Invitrogen-Life Technologies, Milan, Italy. Cytochalasin-B, Mitomycin-C (MMC), BP-A and Giemsa stain solution were obtained from Sigma-Aldrich, Milan, Italy. Methanol, Acetic acid, and conventional microscope slides were purchased from Carlo Erba Reagenti, Milan, Italy. Potassium chloride $(\mathrm{KCl})$ and Sörensen buffer were obtained from Merck S.p.A., Milan, Italy. Vacutainer blood collection tubes were from Terumo Europe, Rome, Italy.

\subsection{Subjects}

Peripheral venous blood was collected from 5 healthy female subjects (mean age \pm S.D., 27.60 \pm 5.22 , range 22-30 years), non-smoking, non-alcoholic, not under drug therapy, and with no recent history of exposure to mutagens. Informed consent was obtained from all blood donors. The study was approved by the Univeristy of Turin ethics committee and was performed in accordance with the ethical standards laid down in the 1964 Declaration of Helsinki. 


\subsection{Blood Sample Collection and Lymphocyte cultures}

Heparinized blood samples were obtained by venipuncture and collected in heparinised tubes, for genotoxicity testing. All blood samples were coded, cooled $\left(4^{\circ} \mathrm{C}\right)$, and processed within $2 \mathrm{~h}$ after collection. Heparinized venous blood $(0.3 \mathrm{~mL})$ was cultured in $25 \mathrm{~cm}^{2}$ flasks in $6 \mathrm{~mL}$ of RPMI1640 medium supplemented with 20\% foetal calf serum (FCS), $2 \%$ of the mitogenic agent PHA, Lglutamine $(2 \mathrm{mM})$, antibiotics (100 IU/mL penicillin, and $100 \mu \mathrm{g} / \mathrm{mL}$ streptomycin). The cultures were incubated for $72 \mathrm{~h}$ at $37^{\circ} \mathrm{C}$, under $5 \%$ of $\mathrm{CO}_{2}$ in the air in a humidified atmosphere. After $24 \mathrm{~h}$ of incubation, BP-A dissolved in DMSO (for stock solution preparation $200 \mu \mathrm{g}$ of BP-A were dissolved in $1 \mathrm{~mL}$ of DMSO) was added to the cultures to a final concentrations of $0.20 \mu \mathrm{g} / \mathrm{mL}$, $0.10 \mu \mathrm{g} / \mathrm{mL}, 0.05 \mu \mathrm{g} / \mathrm{mL}, 0.02$ and $0.01 \mu \mathrm{g} / \mathrm{mL}$. The concentration at $0.05 \mu \mathrm{g} / \mathrm{mL}$ represents the RD established by US EPA ${ }^{28}(0.05 \mathrm{mg} / \mathrm{kg} \mathrm{BW}) ; 0.20 \mu \mathrm{g} / \mathrm{mL}$ and $0.10 \mu \mathrm{g} / \mathrm{mL}$ are multiples of this RD; $0.020 \mu \mathrm{g} / \mathrm{mL}$ represents the higher concentration of unconjugated BP-A found in literature in human serum, ${ }^{15}$ and $0.01 \mu \mathrm{g} / \mathrm{mL}$ is the TDI established by EU ${ }^{14}(10 \mu \mathrm{g} / \mathrm{kg} \mathrm{BW})$.

Three control cultures were assessed: 1) positive control, by adding only MMC (final concentration $0.1 \mu \mathrm{g} / \mathrm{mL}$ culture); 2) solvent control, by adding only $0.1 \%$ of DMSO; 3 ) negative control, culture without both BP-A and DMSO. Only for MNs assay, after $44 \mathrm{~h}$ of incubation, cytochalasin-B was added to the cultures at a concentration of $6 \mu \mathrm{g} / \mathrm{mL}$ to block cytokinesis.

After $48 \mathrm{~h}$ (for CAs assay) and $72 \mathrm{~h}$ (for MNs assay) of incubation at $37^{\circ}$, the cells were collected by centrifugation and treated for 10 min with a pre-warmed mild hypotonic solution $(75 \mathrm{mM} \mathrm{KCl})$. After centrifugation and removal of the supernatant, the cells were fixed with a fresh mixture of methanol/acetic acid $(3: 1 \mathrm{v} / \mathrm{v})$. The treatment with the fixative was repeated three times. Finally, the supernatant was discarded and the pellet, dissolved in a minimal volume of fixative, was seeded on the slides to detect CAs and MNs by conventional staining with 5\% Giemsa (pH 6.8) prepared in Sörensen buffer.

\subsection{Cytokinesis-Block Micronucleus Assay}


Microscope analysis was performed at 40X magnification on a light microscope (Dialux 20, Leica, Germany). MNs were scored in 1000 binucleated lymphocytes with well-preserved cytoplasm per subject (total 5000 binucleated cells per concentration), following the established criteria for MNs evaluation. ${ }^{32}$ A total of 1000 lymphocytes per donor per concentration were scored to evaluate the percentage of cells with 1-4 nuclei. The cytokinesis-block proliferation index (CBPI) was calculated, according to the following formula: $[1 \times \mathrm{N} 1]+[2 \times \mathrm{N} 2]+[3 \times(\mathrm{N} 3+\mathrm{N} 4)] / \mathrm{N}$, where N1-N4 represents the number of cells with 1-4 nuclei, respectively, and $\mathrm{N}$ is the total number of cells scored.

\subsection{Chromosomal Aberrations Assay}

Microscope analysis was performed at 1000X magnification on a light microscope (Dialux 20, Leica, Germany). Althogh the Organization for Economic Co-operation and Development (OECD) guidelines call for 300 metaphases to be scored for each dose, ${ }^{33}$ in order to obtain results more significant and suitable for statistical analysis, it is the normal practice in our laboratory to score 200 metaphases per subject per dose. Thus, in the present work, for each subject and BP-A concentration, 200 well-spread first-division complete metaphases (for a total of 1000 metaphases for each dose) containing $46 \pm 1$ chromosomes were analysed for the following categories of CAs: gaps, chromatid breaks (B'), chromosome breaks (B”), dicentrics (Dic), rings (R), tri- or tetraradials (TR), acentric fragments (AF), rearrangements (Re) and numerical aberrations. Cells containing one of more types of CAs were scored as "aberrant cell" (Ab.C).

With regard to the opportunity to include gaps in the statistical analyses, the discussion is open. Although some authors considered gaps as the appropriate indicator of genotoxic potential of chemicals, ${ }^{34}$ the molecular mechanism of BP-A to induce achromatic lesion/gaps is yet to be revealed. Thus, in our statistical analyses we decided to exclude gaps.

\subsection{Statistical analysis}


Comparison of mean values of the percentage of cells with MNs, CBPI and CAs between exposition levels and their controls was assessed by the non-parametric Wilcoxon Mann-Whitney $U$ test. Statistical calculations were carried out using the SPSS software package program (version 23.0, Inc., Chicago, IL, USA). All P values were two tailed, and P values of 5\% or less were considered statistically significant for all tests carried out.

\section{Results}

\subsection{Effect of BP-A on CAs formation}

Table 1 shows values of CAs found in the human peripheral lymphocytes cultured in the presence of different concentrations of BP-A. BP-A was found to induce seven types of structural CAs (gaps, chromatid and chromosome breaks, dicentric chromosomes, rings, tri- or tetraradials, acentric fragments and rearrangements). No numerical aberrations were found.

Data obtained indicated that human lymphocytes treated in vitro with BP-A at concentrations of $0.20,0.10$ and $0.05 \mu \mathrm{g} / \mathrm{mL}$ significantly increased the CAs frequency compared with the solvent control, whereas at the lower concentrations of 0.02 and $0.01 \mu \mathrm{g} / \mathrm{mL}$ this effect was not observed. Among tested concentrations, significant differences were found between 0.02 and $0.01 \mu \mathrm{g} / \mathrm{mL}$ and the other three tested concentrations (with p-value of $P=0.001, P=0.028$ and $P=0.023$, respectively, for $0.02 \mu \mathrm{g} / \mathrm{mL}$ and $P<0.001, P=0.006$ and $P=0.006$, respectively, for 0.01 $\mu \mathrm{g} / \mathrm{mL})$, as well as between the higher tested concentration $(0.20 \mu \mathrm{g} / \mathrm{mL})$ and $0.05 \mu \mathrm{g} / \mathrm{mL}(P=$ 0.010). As already observed in our previous work, the DMSO solvent-control cultures did not show any difference compared to the control cultures $(P=0.058)$ confirming that, at this low dose (0.1\%), DMSO has no relevant biological effects. Finally, as expected, control cultures treated with the known mutagen MMC showed a significant increase of CAs with respect to all BP-A tested concentrations $(P<0.001)$, as well as to the negative and solvent control cultures $(P<0.001)$.

\subsection{Effect of BP-A on MNs formation}


To verify both the aneugenic and clastogenic effects of BP-A, the MN test was assessed in parallel with CAs test (Table 2). Our results indicated that BP-A significantly, and in a dose-dependent manner, increased the MNs formation compared with the negative and solvent controls, at all concentrations tested, including $0.02 \mu \mathrm{g} / \mathrm{mL}$, that represents the higher concentration of unconjugated BP-A found in literature in human serum. ${ }^{2}$ Similarly to what we already observed with the CAs assay, at the concentration of $0.01 \mu \mathrm{g} / \mathrm{mL}$, that represent the TDI established by EU, ${ }^{14}$ no significant cytogenetic effects were observed.

The highest tested concentration $(0.20 \mu \mathrm{g} / \mathrm{mL})$ caused a fourfold increase of MNs as compared with the solvent culture. Moreover, significant differences in MNs frequency were also found between $0.20 \mu \mathrm{g} / \mathrm{mL}$ and all other concentrations, as well as between $0.10 \mu \mathrm{g} / \mathrm{mL}$ and the last two lower concentrations $(0.02$ and $0.01 \mu \mathrm{g} / \mathrm{mL})$. The solvent-control cultures did not show any difference with the negative controls $(P=0.059)$, further confirming that at this low concentration DMSO has no cytogenetic effects. Similarly to what we observed with CAs assay, cultures treated with the mutagen MMC showed a substantially increased MNs formation compared with the negative control, solvent controls and all tested concentrations of BP-A. Finally, after 48-h exposure, a significant reduction of the CBPI value in cultures treated with BP-A was not observed, indicating that BP-A does not seem to produce effects on the proliferation/mitotic index when its concentration is equal or less than $0.20 \mu \mathrm{g} / \mathrm{mL}$. 


\section{Discussion}

The genotoxicity of BP-A has been evaluated in several in vitro and in vivo studies, although with controversial results. ${ }^{22,23,24,26}$ Here, we discuss data obtained from our in vitro study conducted in order to establish the clastogenic and aneugenic potential of BP-A on human cultured lymphocytes. The results obtained in the present in vitro study with CAs and MNs assays evidenced a possible clastogenic effect of the BP-A on human lymphocytes, also at the concentration of $0.05 \mu \mathrm{g} / \mathrm{mL}$ that represents the reference dose established for humans by the US EPA. ${ }^{28}$ This result is consistent with that obtained by Tayama et al., ${ }^{35}$ who demonstrated that BP-A, in cultured CHO-K1 cells, is able to induce significant structural CAs, like gaps, breaks and exchanges. Similarly, Xin et al. ${ }^{22}$ observed a significant increase of MNs frequency in CHO cells after $24 \mathrm{~h}$ exposure to doses of 80 and $120 \mu \mathrm{M}$ of BP-A (corresponding to 0.018 and $0.027 \mu \mathrm{g} / \mathrm{mL}$, respectively). Finally, Parry et al. ${ }^{20}$ and Johnson and Parry ${ }^{36}$ showed that BP-A cause MNs induction, also in these cases in a dosedependent manner, on MCL5 and AHH-1 human lymphoblastoid cell lines and Chinese hamster V79 cells.

The increase of cytogenetic damage observed with both CAs and MNs assays at concentration of $0.05 \mu \mathrm{g} / \mathrm{mL}$ pushes towards the adoption of lower reference limits. Indeed, increased CAs and MNs frequencies in peripheral blood lymphocytes have been positively associated with increased cancer risk and early events in carcinogenesis, respectively. ${ }^{29,31}$ Vice versa, at the concentration of 0.01 $\mu \mathrm{g} / \mathrm{mL}$, the TDI established by the EU $(2002){ }^{14}$, no cytogenetic effects were observed, indicating that this latter represents a more safe concentration for human health with respect to $0.05 \mu \mathrm{g} / \mathrm{mL}$. The clastogenic properties of the BP-A were attributed by Adamkis et al. ${ }^{37}$ to its capacity to interact with the cell microtubules causing their depolymerization and consequent manifestation of chromosomal abnormalities. Moreover, it is evident from the literature that BP-A is able to generate ROS by decreasing the activities of antioxidant enzymes and increasing lipid peroxidation. A possible consequence of this action could be the increase of the cellular oxidative stress that is considered one of the possible mechanisms underlying DNA damage. ${ }^{38}$ BP-A was also found to be 
able to up-regulate the expression of ERCC5 encoding a DNA endonuclease involved in nucleotide-excision repair. This is an important issue because a reduced repair capacity has been reported to be associated with increased risk of genomic damage and cancer development. ${ }^{39}$ However, we cannot ascribe the observed cytogenetic damage exclusively to the direct effect of BP-A on lymphocytes. Indeed, in vitro studies showed that BP-A is converted to DNA-binding metabolites. In particular, BP-A is oxidized to bisphenol-o-quinone whose chemical reaction with DNA produces adducts in vitro and in vivo. ${ }^{40}$ The irreversible binding of BP-A derived compounds to DNA could cause bases loss from the DNA strand and could be responsible for some of the BPA observed toxic effects. It is known that many chemicals, either directly or after conversion to reactive metabolites, covalently modify nucleosides of DNA leading to mutational changes and, thus, playing a role in cellular toxicity or tumorigenesis induction. ${ }^{40}$

Moreover, it should be also emphasized that the link between observed toxicological effects and BP-A exposure, especially at low doses, is complicated by the fact that BP-A is prevalent in many consumer products, including common laboratory plastics, and has the potential to leach from these products. Consequently, these background concentrations of BP-A have the potential to affect the results of in vitro studies that detect low concentration effects. ${ }^{41}$ Indeed, some in vitro studies showed that BP-A induces significant effects also to nominal concentrations. For example, a BP-A concentration of $0.23 \mathrm{pg} / \mathrm{mL}$ was found to promote proliferation of human seminoma cells (JKT$1) .^{42}$

Interestingly, BP-A increased MNs frequency also at the concentration of $0.02 \mu \mathrm{g} / \mathrm{mL}$, where CAs failed. These apparently discordant results could be explained by the fact that the MNs assays reveal alterations in either chromosome number or chromosome structure, whereas the CAs analysis can detect alterations only in the chromosome structure. One of the mechanisms of action of aneugenic chemicals is the induction of alterations to centromeric DNA, with consequent failure of the damaged chromosomes to attach to the mitotic spindle. As also postulated by other authors for other xenobiotics ${ }^{43}$, it is possible that BP-A may also damage the chromosomes centromeres, 
determining MNs formation. Moreover, disruption of the mitotic machinery, i.e. microtubules and microtubule organizing centers, has been shown to be the mechanism of action for BP-A induced spindle-damaging effects. ${ }^{44}$ In this scenario it can be hypothesized that BP-A might induce aneuploidy through non-disjunction.

\section{Conclusion}

In conclusion, the results reported herein demonstrate cytogenetic effects of BP-A on cultured human lymphocytes by increasing MNs and CAs frequencies. A large number of studies showing the clastogenic and toxic properties of BP-A were performed using different cell models. For these reasons, although simple experimental models, like mammalian and bacterial cells, cannot accurately mimic the complex kinetics of xenobiotic compounds in vivo, our results suggest the adoption of more stringent measures in order to reduce the presence of this compound in the environment and to minimize the adverse health effects of BP-A exposure. Finally, being BP-A converted in vivo and in vitro in DNA binding metabolites, it would be useful and interesting to test in vitro also the genotoxicity of the BP-A metabolites or a combination of both BP-A and its metabolites. Indeed, BP-A was found to have a short half-life (47 h in H295R cells) ${ }^{45}$ and therefore it is conceivable that in in vitro systems about $50 \%$ of BP-A could not be metabolized after $48 \mathrm{~h}$ treatment (typical of MNs assay) and more than 50\% after $24 \mathrm{~h}$ treatment (typical of CAs assay). In this sense, a combined genotoxic action of both BP-A and its metabolites cannot be excluded.

\section{Acknowledgment}

We are grateful to all volunteers who participated in this study.

\section{Conflict of Interest}

The authors declare no conflicts of interest, with respect to the authorship and/or publication of this article.

\section{Funding}


This research was supported by grant from the Italian Ministry of University and Scientific Research (“ex 60\%”).

\section{References}

1) Crain DA, Eriksen M, Iguchi T, Jobling S, Laufer H, LeBlanc GA and Guillette LJ Jr. Anecological assessment of bisphenol-A: evidence from comparative biology. Reprod Toxicol 2007; 24: 225-239.

2) Vandenberg LN, Hauser R, Marcus M, Olea N and Welshons WV. Human exposure to bisphenol A (BPA). Reprod Toxicol 2007; 24: 139-177.

3) Amanti-Kandarakis E, Bourguignon JP, Giudice LC, Hauser R, Prins GS, Soto AM, Zoeller RT and Gore AC. Endocrine-disrupting chemicals: an endocrine society scientific statement, Endocr Rev 2009; 30: 293-342

4) Liao C, Liu F, Moon HB, Yamashita N, Yun S and Kannan K. Bisphenol analogues in sediments from industrialized areas in the United States, Japan, and Korea: spatial and temporal distributions. Environ Sci Technol 2012; 46: 11558-11565

5) Tao S, Zhang Y, Yuan C, Gao J, Wu F, and Wang Z. Oxidative stress and immunotoxic effects of bisphenol A on the larvae of rare minnow Gobiocypris rarus. Ecotoxicol Environm Safety 2016; 124: 377-385

6) Ariemma F, D'Esposito V, Liguoro D, Oriente F, Cabaro S, Liotti A, Cimmino I, Longo M, Beguinot F, Formisano P, and Valentino R. Low-Dose Bisphenol-A Impairs Adipogenesis and Generates Dysfunctional 3T3-L1 Adipocytes. PLoS One 2016; 11(3): e0150762

7) Kang JH, Kito K, and Kondo F. Factors influencing the migration of bisphenol A from cans. J Food Prot 2004; 66: 1444-1447

8) Kubwabo C, Kosarac I, Stewart B, Gauthier BR, Lalonde K, and Lalonde PJ. Migration of bisphenol A from plastic baby bottles, baby bottle liners and reusable polycarbonate drinking bottles. Food Addit Contam Part A: Chem Anal Control Expo Risk Assess 2009; 
26: $928-937$

9) Rogers JA, Metz L, and Yong VW. Review: Endocrine disrupting chemicals and immune responses: A focus on bisphenol-A and its potential mechanisms. Mol Immunol 2013; 53(4): 421-430.

10) Calafat AM, Kuklenyik Z, Reidy JA, Caudill SP., Ekong J, and Needham LL. Urinary concentrations of bisphenol A and 4-nonylphenol in a human reference population. Environ. Health Perspect 2005; 133: 391-395

11) Ikezuki Y, Tsutsumi O, Takai Y, Kamei Y, and Taketani Y. Determination of bisphenol A concentrations in human biological fluids reveals significant early prenatal exposure. Hum Reprod 2002; 17: 2839-2841

12) Schonfelder G, Wittfoht W, Hopp H, Tallness CE, Paul M, and Chahoud I. Parent bisphenol A accumulation in the human maternal-fetal-placental unit. Environ. Health Perspect 2002; 110: A703-A707.

13) Sun Y, Irie M, Kishikawa N, Wada M, Kuroda N and Nakashima K. Determination of bisphenol A in human breast milk by HPLC with column-switching and fluorescence detection. Biomed Chromatogr 2004; 18: 501-507.

14) EU-Report (2002). Draft risk assessment of bisphenol A (carried out in accordance with the Council Regulation (EEC) 793/93 on the evaluation and control of the risks of "existing" substances), Rapporteur, United Kingdom (Contact: Environment Agency, Chemicals Assessment Section, Oxfordshire, U.K.).

15) Völkel W, Colnot T, Csanády GA, Filser JG and Dekant W. Metabolism and Kinetics of Bisphenol A in Humans at Low Doses Following Oral Administration. Chem Res Toxicol $2002 ; 15: 1281-1287$

16) Toft G, Hagmar L, Giwercman A and Bonde JP. Epidemiological evidence on reproductive effects of persistent organochlorines in humans. Reprod Toxicol 2004; 19: 5-26.

17) Pflieger-Bruss S, Schuppe HC and Schill W. The male reproductive system and its 
susceptibility to endocrine disrupting chemicals. 2004; Andrologia 36: 337-345.

18) Niclopoulou-Stamati P and Pitsos MA. The impact of endocrine disrupters on the female reproductive system. Hum Reprod Update 2001; 7: 323-330.

19) Tsutsui T, Tamura Y, Yagi E, Hasegawa K, Takahashi M, Maizumi N, Yamaguchi F and Barrett JC. Bisphenol-A induces cellular transformation, aneuploidy and DNA adduct formation in cultured Syrian hamster embryo cells. Int J Cancer 1998; 75(2): 290-294

20) Parry EM, Parry JM, Corso C, Doherty A, Haddad F, Hermine TF, Johnson G, Kayani M, Quick E, Warr T and Williamson J. Detection and characterization of mechanisms of action of aneugenic chemicals. Mutagenesis 2002; 17: 509-521.

21) Bolognesi C, Perrone E, Roggieri P, Pampanin DM and Sciutto A. Assessment of micronuclei induction in peripheral erythrocytes of fish exposed to xenobiotics under controlled conditions. Aquat Toxicol 2006; 78(1): S93-S98

22) Xin L, Lin Y, Wang A, Zhu W, Liang Y, Su X, Hong C, Wan J., Wang Y and Tian H. Cytogenetic evaluation for the genotoxicity of bisphenol-A in Chinese hamster ovary cells. Environ Toxicol Pharmaco. 2015; 40(2): 524-529

23) Šutiaková I, Kovalkovičová N and Šutiak V. Micronucleus assay in bovine lymphocytes after exposure to bisphenol A in vitro. In Vitro Cell Dev Biol Anim 2014; 50(6): 502-506.

24) Tiwari D, Kamble J, Chilgunde S, Patil P, Maru G, Kawle D, Bhartiya U, Joseph L and Vanage G. Clastogenic and mutagenic effects of bisphenol A: An endocrine disruptor. Mutat Res 2012; 743(1-2): 83-90.

25) Yin R, Gu L, Li M, Jiang C, Cao T and Zhang X. Gene Expression Profiling Analysis of Bisphenol A-Induced Perturbation in Biological Processes in ER-Negative HEK293 Cells. Plos-One 2014; 9(6): e98635.

26) Pacchierotti E, Ranaldi R, Eichenlaub-Titter U, Attia S and Adler ID. Evaluation of aneugenic effects of Bisphenol-A in somatic and germ cells of mouse. Mutat Res 2008; 651: 64-70. 
27) Tennant RW, Margolin BH, Shelby MD, Zeiger E, Haseman JK and Spalding J. Prediction of chemical carcinogenicity in rodents from in vitro genetic toxicity assays. Science 1987; 236: 933-941.

28) US EPA (United States Environmental Protection Agency) (1988). Bisphenol A Reference Dose for Chronic Oral Exposure (RfD) in Integrated Risk Information System (IRIS), A Toxicology Data File on the National Library of Medicine's (NLM) TOXNET System.

29) Bonassi S, Znaor A, Norppa H, Hagmar L. Chromosomal aberrations and risk of cancer in humans: an epidemiologic perspective. Cytogenet Gen Res 2004; 104: 376-382.

30) Garcia-Sagredo JM. Fifty years of cytogenetics: a parallel view of the evolution of cytogenetics and genotoxicology. Biochim. Biophys. Acta 2008; 1779(6-7): 363-375.

31) Bonassi S, El-Zein R and Bolognesi C. Micronuclei frequency in peripheral blood lymphocytes and cancer risk: evidence from human studies. Mutagenesis 2011; 26: 93-100.

32) Fenech M, Chang WP, Kirsch-Volders M, Holland N, Bonassi S and Zeiger E. HUman MicronNucleus project (HUMN project): detailed description of the scoring criteria for the cytokinesis-block micronucleus assay using isolated human lymphocyte cultures. Mutat Res $2003 ; 534(1-2): 65-75$.

33) OECD (Organization for Economic Co-operation and Development). Guidance Documents on Revisions to OECD Genetic Toxicology Test Guidelines. https://www.oecd.org/env/ehs/testing/Draft Guidance Document on OECD Genetic Toxicology Test Guidelines.pdf. 2015; 31. Accessed in date 08-22-2016.

34) Savage JR. On the nature of visible chromosomal gaps and breaks. Cytogen Genome Res 2004; 104(1-4): 46-55.

35) Tayama S, Nakagawa Y and Tayama K. Genotoxic effects of environmental estrogen-like compounds in CHO-K1 cells. Mutat Res 2008; 649(1-2): 114-125

36) Johnson GE and Parry EM. Mechanistic investigations of low dose exposures to the genotoxic compounds bisphenol A and rotenone. Mutat Res 2008; 651: 56-63 
37) Adamkis IDS, Panteris E, Cherianidou A and Eleftheriou PE. Effects of bisphenol A on the microtubule arrays in root meristematic cells of Pisum sativum L. Mutat Res 2013; 750: 111-120.

38) Bindhumol V, Chitra KC and Mathur PP. Bisphenol A induces reactive oxygen species generation in the liver of male rats. Toxicology 2003; 188: 117-124

39) Berwick M and Vineis P. Markers of DNA repair and susceptibility to cancer in humans: an epidemiologic review. J Natl Cancer Inst 2000; 92(11): 874-897

40) Atkinson A and Roy D. In vitro conversion of environmental estrogenic chemical bisphenol A to DNA binding metabolite(s). Biochem Biophys Res Commun 1995a; 210(2): 424-433

41) McDonald GR, Hudson AL, Dunn SM, You H, Baker GB, Whittal RM, Martin JW, Jha A, Edmondson DE and Holt A. Bioactive contaminants leach from disposable laboratory plasticware. Science 2008; 322:917

42) Bouskine A, Nebout M, Brucker-Davis F, Benahmed M and Fenichel P. Low doses of bisphenol A promote human seminoma cell proliferation by activating PKA and PKG via a membrane G-protein-coupled estrogen receptor. Environ Health Perspect 2009; 117:10531058.

43) Yüzbaşioğlu D, Celik M, Yilmaz S, Unal F and Aksoy H. Clastogenicity of the fungicide afugan in cultured human lymphocytes. Mutat Res 2006; 604(1-2): 53-59.

44) George O, Bryant BK, Chinnasamy R, Corona C, Arterburn JB and Shuster CB. Bisphenol A directly targets tubulin to disrupt spindle organization in embryonic and somatic cells. ACS Chem Biol 2008; 3(3): 167-179

45) Zhang X, Chang H, Wiseman S, He Y, Higley E, Jones P, Wong CKC, Al-Khedhairy A, Giesy JP and Hecker M. Bisphenol A Disrupts Steroidogenesis in Human H295R Cells. Toxicol Sciences 2011; 121(2): 320-327. 
Table 1 - Induction of chromosomal aberrations by Bisphenol-A in human lymphocytes in vitro.

\begin{tabular}{|c|c|c|c|c|c|c|c|c|c|c|c|c|c|c|c|c|c|}
\hline \multirow{2}{*}{$\begin{array}{c}\text { Test } \\
\text { substance }\end{array}$} & \multicolumn{2}{|c|}{ Treatment } & \multirow{2}{*}{$\begin{array}{c}\text { Total } \\
\text { Scored } \\
\text { Metaphases }\end{array}$} & \multicolumn{8}{|c|}{ CAs } & \multirow{2}{*}{$\begin{array}{l}\text { Total } \\
\text { CAs }\end{array}$} & \multirow{2}{*}{$\begin{array}{c}\text { Total } \\
\text { CAs } \\
+ \\
\text { Gaps }\end{array}$} & \multirow{2}{*}{$\begin{array}{l}\text { Total } \\
\text { Ab.C }\end{array}$} & \multirow{2}{*}{$\begin{array}{c}\text { Total } \\
\text { Ab.C } \\
+ \\
\text { Gaps }\end{array}$} & \multirow{2}{*}{$\begin{array}{c}\text { CAs } / \text { Cell } \pm \text { S.E. } \\
(\%)\end{array}$} & \multirow{2}{*}{ 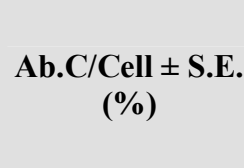 } \\
\hline & & $(\mu \mathrm{g} / \mathrm{ml})$ & & Gaps & B' & B', & DC & $\mathbf{R}$ & TR & $\mathbf{A F}$ & $\mathbf{R e}$ & & & & & & \\
\hline $\mathrm{NC}$ & ---- & ---- & 1000 & 2 & 2 & 0 & 1 & 0 & 0 & 1 & 0 & 4 & 6 & 4 & 6 & $0.40 \pm 0.10^{\$}$ & $0.40 \pm 0.10^{\$}$ \\
\hline $0.1 \%$ DMSO & 24 & $\begin{array}{ll}--- \\
\end{array}$ & 1000 & 8 & 7 & 1 & 1 & 0 & 2 & 1 & 1 & 13 & 21 & 13 & 21 & $1.30 \pm 0.30$ & $1.30 \pm 0.30$ \\
\hline MMC & 24 & 0.10 & 1000 & 38 & 35 & 24 & 11 & 6 & 14 & 26 & 10 & 126 & 164 & 123 & 161 & $12.60 \pm 1.30^{\&}$ & $12.30 \pm 1.00^{\&}$ \\
\hline BP-A & 24 & 0.20 & 1000 & 17 & 29 & 7 & 10 & 1 & 0 & 18 & 5 & 70 & 87 & 70 & 87 & $7.00 \pm 0.70^{*}$ & $7.00 \pm 0.70^{*}$ \\
\hline BP-A & 24 & 0.10 & 1000 & 16 & 22 & 3 & 5 & 2 & 2 & 8 & 7 & 49 & 65 & 49 & 65 & $4.90 \pm 0.60 * *$ & $4.90 \pm 0.60 * *$ \\
\hline BP-A & 24 & 0.05 & 1000 & 8 & 17 & 3 & 5 & 0 & 0 & 11 & 6 & 42 & 50 & 41 & 50 & $4.20 \pm 0.90 * * *$ & $4.10 \pm 0.90 * * *$ \\
\hline BP-A & 24 & 0.02 & 1000 & 8 & 6 & 2 & 2 & 2 & 0 & 7 & 6 & 25 & 33 & 25 & 33 & $2.50 \pm 0.40$ & $2.50 \pm 0.40$ \\
\hline BP-A & 24 & 0.01 & 1000 & 6 & 5 & 2 & 1 & 1 & 0 & 5 & 5 & 19 & 25 & 19 & 25 & $1.90 \pm 0.30$ & $1.90 \pm 0.30$ \\
\hline
\end{tabular}

$\mathrm{CAs}=$ chromosomal aberrations; Ab.C = aberrant cells (cells with 1 ore more aberrations); $\mathrm{NC}=$ Negative Control; $\mathrm{MMC}=\mathrm{Mitomycin}-\mathrm{C}$;

BP-A = bisphenol-A; B': chromatid break; B' : chromosome break; DC: dicentric; R: ring; TR = tri-tetraradials; $\mathrm{AF}=$ acentric fragments;

$\mathrm{Re}=$ rearrangements; S.E. $=$ standard error.

$P<0.001^{*}, P=0.001^{* *}$ and $P=0.002^{* * *}$ with respect to DMSO control; $P<0.001^{\&}$ with respect to all BP-A concentration and DMSO control.

$P<0.001^{\$}$ with respect to all BP-A concentrations 
Table 2 - Induction of micronuclei by Bisphenol-A in human lymphocytes in vitro.

\begin{tabular}{|c|c|c|c|c|c|c|c|c|c|c|c|c|}
\hline $\begin{array}{c}\text { Test } \\
\text { substance }\end{array}$ & \multicolumn{2}{|c|}{\begin{tabular}{cc}
\multicolumn{2}{c}{ Treatment } \\
Period & Dose \\
(h) & $(\mu \mathrm{g} / \mathrm{ml})$
\end{tabular}} & $\begin{array}{l}\text { BNCs } \\
\text { scored }\end{array}$ & \multicolumn{4}{|c|}{$\begin{array}{l}\text { Distribution of BNCs } \\
\text { according to the } \\
\text { number of } \mathrm{MN}\end{array}$} & MNs & Ab.C & $\begin{array}{c}\text { MN/cell } \pm \text { S.E. } \\
(\% 0)\end{array}$ & $\begin{array}{c}\text { Ab.C/cell } \pm \text { S.E. } \\
(\%)\end{array}$ & $\mathbf{C B P I} \pm \mathbf{S . E}$ \\
\hline $\mathrm{NC}$ & ---- & $\begin{array}{l}--- \\
\end{array}$ & 5000 & 9 & 1 & 0 & 0 & 11 & 11 & $2.20 \pm 0.20^{\$}$ & $2.20 \pm 0.20^{\$}$ & $1.712 \pm 0.003$ \\
\hline $0.1 \%$ DMSO & 48 & $\begin{array}{ll}--- \\
\end{array}$ & 5000 & 15 & 1 & 1 & 0 & 20 & 16 & $4.00 \pm 0.55$ & $3.20 \pm 0.37$ & $1.565 \pm 0.092$ \\
\hline MMC & 48 & 0.10 & 5000 & 102 & 4 & 3 & 2 & 127 & 121 & $25.40 \pm 1.21 *$ & $24.20 \pm 1.20 *$ & $1.354 \pm 0.019$ \\
\hline BPA & 48 & 0.20 & 5000 & 72 & 2 & 2 & 1 & 86 & 78 & $17.20 \pm 2.31^{*}$ & $15.60 \pm 1.47^{*}$ & $1.584 \pm 0.046$ \\
\hline BPA & 48 & 0.10 & 5000 & 66 & 1 & 0 & 0 & 68 & 65 & $13.60 \pm 1.17 *$ & $13.00 \pm 1.30 * * *$ & $1.546 \pm 0.017$ \\
\hline BPA & 48 & 0.05 & 5000 & 55 & 0 & 3 & 0 & 64 & 56 & $12.80 \pm 1.16^{* *}$ & $11.20 \pm 0.49 * * *$ & $1.585 \pm 0.016$ \\
\hline BPA & 48 & 0.02 & 5000 & 46 & 0 & 0 & 0 & 46 & 46 & $9.20 \pm 1.63 * *$ & $9.20 \pm 1.63 * *$ & $1.633 \pm 0.005$ \\
\hline BPA & 48 & 0.01 & 5000 & 31 & 0 & 0 & 0 & 31 & 25 & $6.20 \pm 0.80$ & $5.00 \pm 0.95$ & $1.640 \pm 0.009$ \\
\hline
\end{tabular}

$\mathrm{BNCs}=$ Binucleated cells; $\mathrm{MNs}=$ micronuclei; $\mathrm{Ab} . \mathrm{C}=$ Aberrant cells (cells with 1 or more MNs); NC = Negative Control;

$\mathrm{MMC}=$ Mitomycin-C; BP-A = Bisphenol-A; S.E. = Standard Error. CBPI = Cytokinesis-Block Proliferation Index.

$P=0.042^{*}, \mathrm{P}=0.043^{* *}$ and $\mathrm{P}=0.039^{* * *}$ with respect to DMSO control. $P<0.001^{\$}$ with respect to all BP-A concentrations and MMC 